\title{
A Survey of Black-footed Albatross Breeding Colonies and Chicks on Torishima, January 1994
}

\author{
Haruo Ogi*, Fumio Sato**, Amane Mitamura**, \\ Takao Baba***, and Hitoshi Oyama****
}

Key words : Hatching rate, Chick weight, Breeding colony, Hatsune-zaki, Tsubamezaki, Black-footed Albatross, Diomedea nigripes, Torishima

The status of the endangered Short-tailed Albatross on Torishima has attracted much attention (Fujisawa 1967, Hasegawa 1982, Hasegawa and DeGange 1982), but the presence of Black-footed Albatrosses on this island has not been well known.

The world population of the Black-footed Albatross is estimated to be 200,000 birds, which is quite small compared with the North Pacific Ocean Laysan Albatross population of 2.5 million birds (McDermon and Morgan 1993). The breeding population of the Black-footed Albatross in the Hawaiian Islands is reported to be slightly declining (McDermon and Morgan 1993), while the population of the Southern Ryukyu, Izu, and Bonin Islands in the western part of the North Pacific has been increased in recent years (Sato unpubl. data). The Torishima population has increased from 300-400 birds in 1980 (Hasegawa 1982) to 700-800 in 1993 (Sato unpubl. data).

We stayed on Torishima from 20 to 28 January 1994 and spent 10 hours at Hatsune-zaki and 8 hours at Tsubame-zaki for the observation of the Black-footed Albatross.

\section{Colonies and Nesting Habitat}

The Hatsune-zaki colony is located on a wide west-side gentle slope at a height of 60$100 \mathrm{~m}$, over an area of about $50,000 \mathrm{~m}^{2}$, covered with rich, perennial plants (Miscanthus condensatus, Chrysanthemum pacificum, and Boehmeria biloba) and a few woody plants (Morus sp., and Elaeagnus sp.) (Fig. 1-A). The breeding colony at Hatsune-zaki has been used by immigrants from Tsubame-zaki since the breeding seasons of 1980/81 and 1981/ 82 (Hasegawa 1982). The nests of Black-foots are distributed here and there in small numbers.

The Tsubame-zaki colony is located on a southeast-side slope over an area of about $90,000 \mathrm{~m}^{2}$, and is surrounded by almost vertical back cliffs $150 \mathrm{~m}$ to $200 \mathrm{~m}$ high and ends at bare-rock cliffs standing 20-40 m from the sea surface (Fig. 1-B). The slope of volcanic

\footnotetext{
Received 18 April 1994, Revised 22 July 1994, Accepted 29 August 1994.

* Research Institute of North Pacific Fisheries, Faculty of Fisheries, Hokkaido University, Hakodate, Hokkaido, 041 Japan.

** The Yamashina Institute for Ornithology, Konoyama, Abiko, Chiba, 270-11 Japan.

*** Japanese Bird Banding Association, Konoyama, Abiko, Chiba, 270-11 Japan.

**** The Society for the Study of Freshwater Fish in Miyagi, Tsurugaya 1-28-14, Miyagino-ku, Sendai, Miyagi, 983 Japan.
} 
sand and gravel spreads in an irregular fan shape, and its higher part is covered by sparse vegetation (B. biloba, and Miscanthus condensatus). On Tsubame-zaki, nesting habitats of the Black-footed Albatross consisted of a sparsely-vegetated area and a wind-blown exposed area. At the sparsely- and richly-vegetated areas, nests of the Black-footed Albatross were cup-shaped and constructed of fine dead branches, dry grasses, and other materials. The nests in the wind-blown exposed area were simply shallow cup-like depressions made in the volcanic sand and gravel.

All Black-footed Albatrosses observed at Hatsune-zaki were making nests over the vegetated slopes (VS: Fig. 1-A). On the other hand, at Tsubame-zaki, more Black-footed Albatrosses nested on the wind-blown exposed areas than on vegetated areas. The nesting
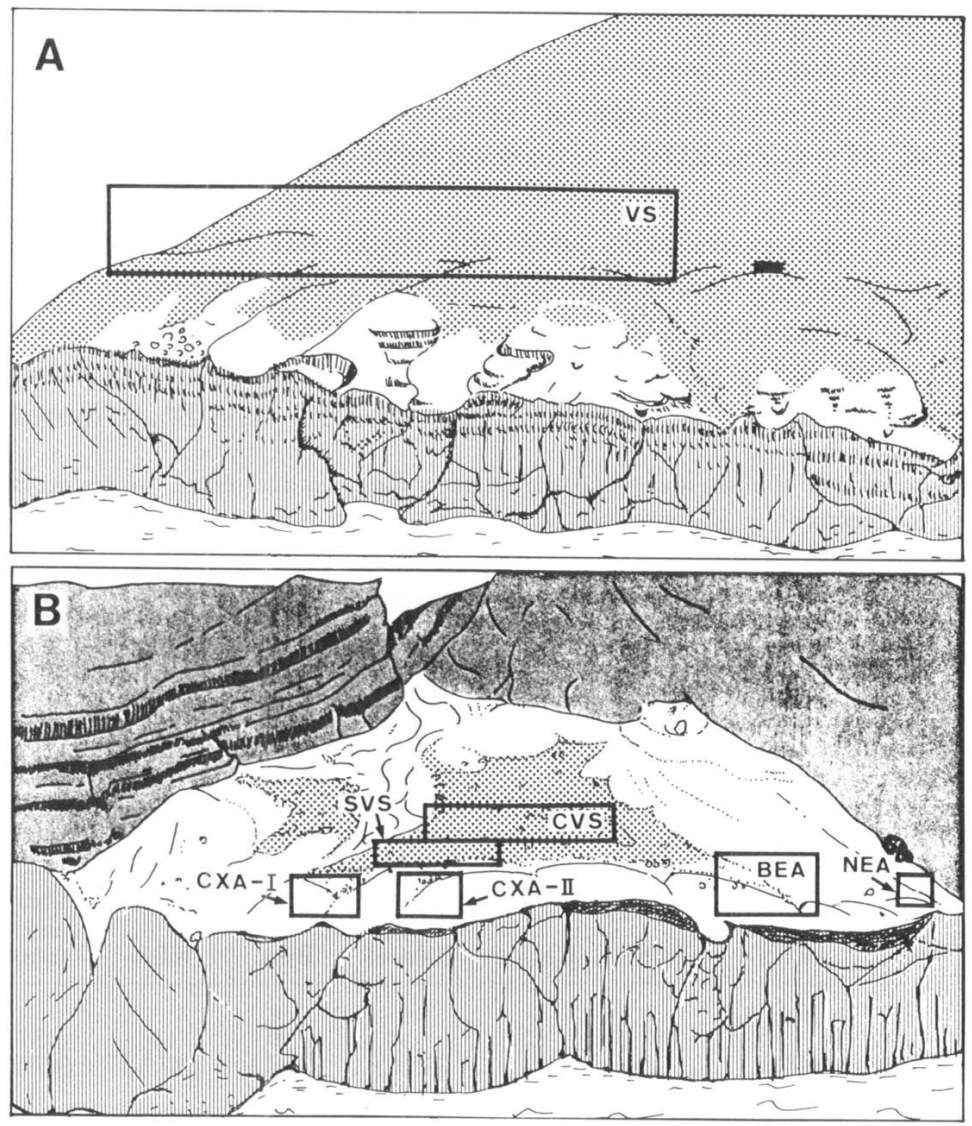

Fig. 1. Nesting colonies of Black-footed Albatrosses at Hatsune-zaki (A), and Tsubame-zaki (B) on Torishima, and nest survey areas showing thick square lines.

The dotted part denotes the vegetated area. A; VS: Vegetated Slope, B; CVS: Central Vegetated Slope, SVS: South Vegetated Slope, CXA-I: Cliff-side Exposed Area-I, CXA-II: Cliffside Exposed Area-II, BEA: Broad Exposed Area, NEA: North-end Exposed Area. See abbreviations also in the text. 
habitats observed at Tsubame-zaki were classified as follows (Fig. 1-B): Central Vegetated Slope (CVS), South Vegetated Slope (SVS), Cliff-side Exposed Area-I (CXA-I), Cliff-side Exposed Area-II (CXA-II), Broad Exposed Area (BEA), and North-end Exposed Area (NEA). At the area NEA, all nests were examined.

\section{Number of Nests, Eggs and Chicks}

We counted only the nests in which an egg or a chick was present, together with one or both parents. Total number of nests was 103 at Hatsune-zaki and 450-500 at Tsubame-zaki, respectively (Table 1). Of these, the latter was roughly estimated from an observed total of 973 birds. Based on these data, the total breeding population of Black-footed Albatrosses on Torishima is estimated to be 1,106-1,206 birds. This population estimate may be conservative, since the breeders which failed to breed during the 1993-94 breeding season were not included in the count.

The proportion of nests with eggs at Hatsune-zaki was greater than that at Tsubamezaki $\left(\chi^{2}=20.04, \mathrm{df}=1, P<0.001\right)$, indicating birds at Tsubame-zaki bred earlier than those at Hatsune-zaki.

Interestingly, the proportion of nests with chicks was always higher in the exposed nesting habitats consisting of volcanic sand and/or gravel than in the vegetated nesting habitats as shown in the Table 1. The comparison of chick occurrence rates between the combined vegetated nesting habitats and the combined exposed nesting habitats showed a highly significant difference $\left(\chi^{2}=9.60, \mathrm{df}=1, P<0.005\right)$. The Black-footed Albatrosses

Table 1. Total number of nests, and proportion of nests with eggs and chicks by nesting colony and nesting habitat.

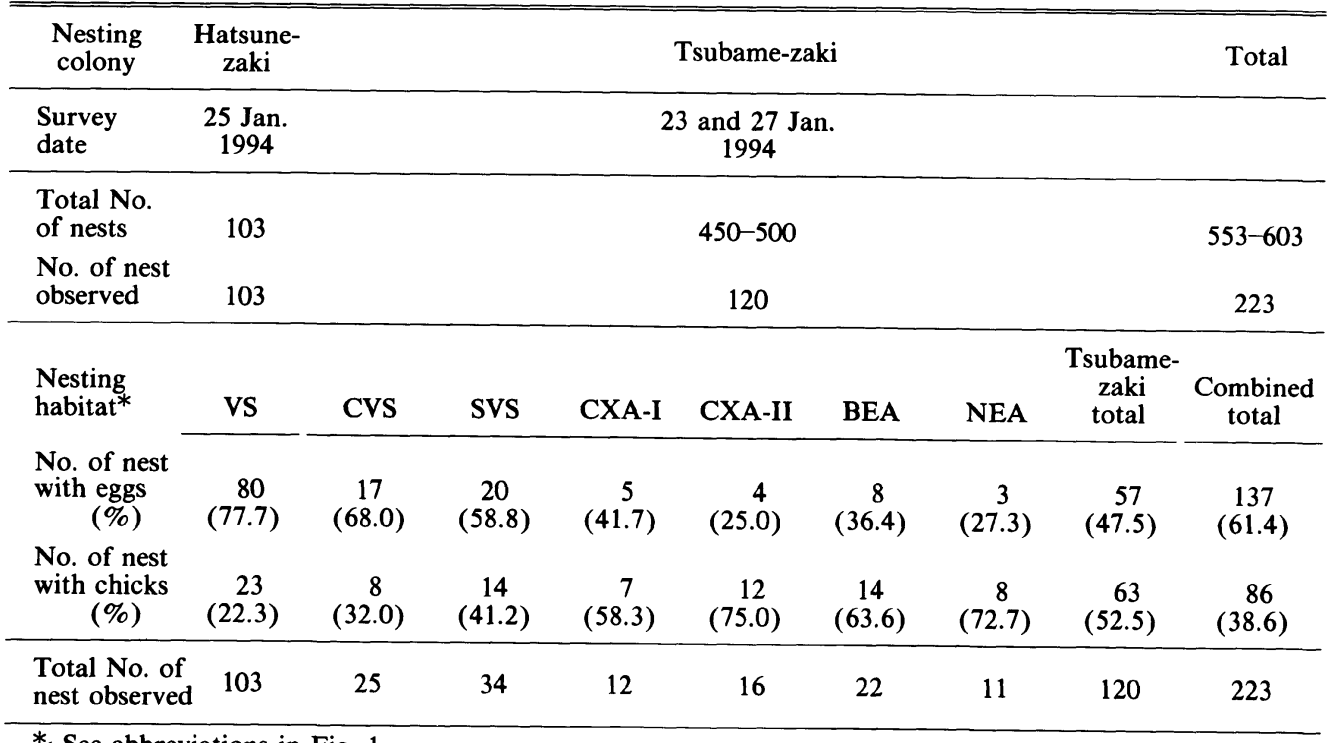

\footnotetext{
*: See abbreviations in Fig. 1.
} 
on Torishima showed a strong preference for making nests at exposed sandy and gravelish sites near the edge of the island, as was similarly reported by Fisher (1904), Bailey (1952), Rice and Kenyon (1962), and Fisher (1972) in the Hawaiian Islands. However, each of the comparisons between nesting habitats in Table 1 did not show a clear difference except for the comparison between CVS and CXA-II $\left(\chi^{2}=5.60, \mathrm{df}=1,0.01<P<0.025\right)$. This seems to be due to the small sample size.

\section{Body Weight of Chicks}

Distributions of chick's body weights by nesting habitats are given in Appendix 1, showing a wide variation of body weights from $160 \mathrm{~g}$ at VS in Hatsune-zaki to $1,200 \mathrm{~g}$ at BEA in Tsubame-zaki. Average chick body weights of the Black-footed Albatross were $317 \pm 96(S D) g(n=15)$ at Hatsune-zaki, and $413 \pm 209($ SD $) g(n=53)$ at Tsubame-zaki, showing a significant difference between the averages $\left(t^{\prime}=2.50,0.01<P<0.025\right)$. The results also show that breeding in the colony at Tsubame-zaki seems to have occurred earlier, in general, than in the colony at Hatsune-zaki.

The range of body weights and coefficient of variation (CV) tended to increase with increasing weight. Vegetated nesting habitats such as Hatsune-zaki (VS), CVS, and SVS showed narrow weight ranges and lower average weights. Exceptionally, at the CXA-I, the average weight and CV showed the lowest values. Nesting environmental conditions in this area may be the worst among all exposed nesting habitats. However, at other exposed nesting habitats, the average weight and CV were $418-540 \mathrm{~g}$ and 44.8-54.4\%, respectively. The average body weights in these exposed nesting habitats were about $100-200 \mathrm{~g}$ heavier than those in the vegetated nesting habitats, not taking into account the CXA-I.

\section{Conclusion}

The timing of breeding of the Black-footed Albatross at Hatsune-zaki appears to have occurred a little later than at Tsubame-zaki. This may be due to the following reasons: the Hatsune-zaki colony is a newly established colony showing a still growing and incomplete colony, and breeders at Hatsune-zaki colony probably consist of a larger proportion of younger adults than those at the Tsubame-zaki colony.

\section{Acknowledgements}

We would like to express our sincere thanks to the Suntory Foundation for Bird Conservation, and the Japanese Environmental Agency, for their financial supports. Many thanks due to the Captain T. Tsuchiya, for kindly offering us his fishing vessel, the Tomo Maru, and J. R. Bower, Faculty of Fisheries, Hokkaido University, for kindly correcting the English of this short note.

Contribution No. 278 of the Research Institute of North Pacific Fisheries, Faculty of Fisheries, Hokkaido University. 


\section{References}

Bailey, A. M. 1952. Laysan and Black-footed Albatrosses. Museum Pictorial No. 6, Denver Museum Natural History, 79pp.

Fisher, W. K. 1904. On the habits of the Laysan Albatross. Auk 21: 8-20.

Fisher, H. I. 1972. Sympatry of Laysan and Black-footed Albatrosses. Auk 89: 381-402.

Fujisawa, T. 1967. Ahodori, Diomedea albatrus. Toko Shoin, Tokyo, 169pp. (in Japanese)

Hasegawa, H. 1982. The breeding status of the Short-tailed Albatross Diomedea albatrus, on Torishima, 1979/80-1980/81. J. Yamashina Inst. Ornithol. 14: 16-24.

Hasegawa, H. and DeGange, A. R. 1982. The Short-tailed Albatross, Diomedea albatrus, its status, distribution and natural history. American Birds 36: 806-814.

McDermond, D. K. and Morgan, K. H. 1993. Status and conservation of North Pacific albatrosses. Pages 70 -81 in K. Vermeer, K. T. Briggs, K. H. Morgan, D. Siegel-Causey (ed.), The status, ecology, and conservation of marine birds of the North Pacific. Spec. Publ. Canadian Wildlife Service.

Rice, D. W. and Kenyon, K. W. 1962. Breeding cycles and behavior of Laysan and Black-footed Albatrosses. Auk 79: 517-567.

\section{4 年 1 月の鳥島におけるクロアシアホゥドリの繁殖状況と雅について}

1994 年 1 月 20-28 日に実施された鳥島のアホウドリの営巣地の分散技術の開発に関する調查時に，同島 で同時に繁殖しているクロアシアホウドリの繁殖状況を調查した。

初寝崎の営巣地で親鳥により卵または雊が保護されていた巣の総数は 103 巣，そして燕崎の営巣地で観 察された総個体数 973 羽より推定した巣の総数は 450-500 巣であった。これらから推定される鳥島の総繁 殖鳥数は，内輪に見積むって 1,106-1,206 羽であった。

燕崎の営巣場での巣の設置場所は, ラセイタソウやイソギクの生えている植生地, そして砂や砂利状の 火山砕㞕物だけからなる裸地の二つに分類できた。 なお, 初寝崎の営巣場所の巣は全て植生地に作られて いた。

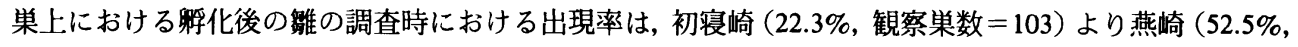
観察巣数 $=120)$ が高く，また雛の平均体重は初寝崎 $(317 \pm 96(\mathrm{SD}) \mathrm{g}, \mathrm{n}=15)$ より燕崎 $(413 \pm 209(\mathrm{SD}) \mathrm{g}$, n=63）が高かった.

燕崎の営巣地を植生地と裸地とに分けて, 雅の調査巣数に対する出現割合と嚾の平均体重を調查してみ ると以下のようになった. 植生地; 雊の出現割合 37.3\% (観察巣数 $=59)$, 平均体重 $347 \pm 144(\mathrm{SD}) \mathrm{g},(\mathrm{n}=$ 15), 裸地; 㮲の出現割合 $67.2 \%$ （観察巣数 $=61)$, 平均体重 $439 \pm 224(\mathrm{SD}) \mathrm{g}, \quad(\mathrm{n}=38)$.

鳥島のクロアシアホゥドリは, 雊の出現時期と体重から判断し, 初寝崎よりも燕崎で早く産卵し, 燕崎に おいては植生地よりも裸地の方が早く産卵したといえる. 初寝崎のコロニーは, こちらに数巣, あちらに数 巣, というように巣の分布はパッチ状であり，コロニーとはいっても未完成である.すなわち新設の営巣地 であり, 繁殖鳥の年齢構成は若齢鳥の多い可能性のあること等から, 繁殖のタイミングが燕崎より遅かっ たと推察される.

小城春雄：北海道大学水産学部, 北洋水産研究施設 $\overline{\mathbf{T}} 041$ 北海道函館市港町 3-1-1

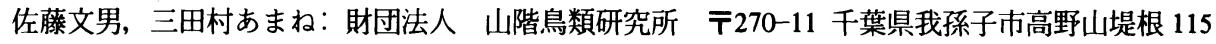

馬場孝夫：日本鳥類標識協会 T270-11 千葉県我孫子市高野山堤根 115

小山 均: 宮城県淡水魚研究会 ₹983 宮城県仙台市宮城野鶴ヶ谷 1-28-14 
Appendix 1. The body weight composition of chicks by nesting habitat.

\begin{tabular}{|c|c|c|c|c|c|c|c|c|c|}
\hline \multirow{3}{*}{$\begin{array}{l}\text { Range of } \\
\text { body } \\
\text { weight } \\
\text { (g) }\end{array}$} & \multicolumn{8}{|c|}{ Number of chicks observed at each nesting habitat } & \multirow{3}{*}{$\begin{array}{c}\text { Combined } \\
\text { total }\end{array}$} \\
\hline & \multirow{2}{*}{$\frac{\begin{array}{c}\text { Hatsune- } \\
\text { zaki }\end{array}}{\text { VS }}$} & \multicolumn{7}{|c|}{ Tsubame-zaki } & \\
\hline & & CVS & SVS & CXA-I & CXA-II & BEA & NEA & total & \\
\hline $151-200$ & 1 & - & - & 1 & - & 1 & - & 2 & 3 \\
\hline $201-250$ & 5 & 4 & 3 & 1 & 3 & - & - & 11 & 16 \\
\hline $251-300$ & 2 & 一 & - & - & 1 & 2 & 1 & 4 & 6 \\
\hline $301-350$ & 2 & 1 & 1 & 2 & 3 & 4 & - & 11 & 13 \\
\hline $351-400$ & - & 1 & - & 1 & - & 2 & 1 & 5 & 5 \\
\hline $401-450$ & 3 & - & 2 & - & - & - & 1 & 3 & 6 \\
\hline $451-500$ & 2 & 1 & - & - & - & - & 1 & 2 & 4 \\
\hline $501-550$ & - & 1 & - & - & - & 2 & 2 & 5 & 5 \\
\hline $551-600$ & - & - & - & - & - & 1 & - & 1 & 1 \\
\hline $601-650$ & - & - & - & - & 3 & 1 & 1 & 5 & 5 \\
\hline $651-700$ & - & - & - & - & - & - & - & 0 & 0 \\
\hline $701-750$ & - & - & 1 & - & 1 & - & - & 2 & 2 \\
\hline : & : & : & : & : & : & : & : & $:$ & : \\
\hline $1101-1150$ & - & - & - & 一 & - & - & 1 & 1 & 1 \\
\hline $1151-1200$ & - & - & - & - & - & 1 & - & 1 & 1 \\
\hline Total & 15 & 8 & 7 & 5 & 11 & 14 & 8 & 53 & 68 \\
\hline Average & 317 & 321 & 377 & 284 & 418 & 454 & 540 & 413 & 392 \\
\hline$\pm \mathrm{SD}$ & 96 & 118 & 164 & 70 & 188 & 242 & 242 & 209 & 194 \\
\hline $\mathrm{CV}(\%)$ & 30.3 & 36.8 & 43.5 & 24.6 & 45.0 & 53.3 & 44.8 & 50.6 & 49.5 \\
\hline
\end{tabular}

See abbreviations in Fig. 1. 

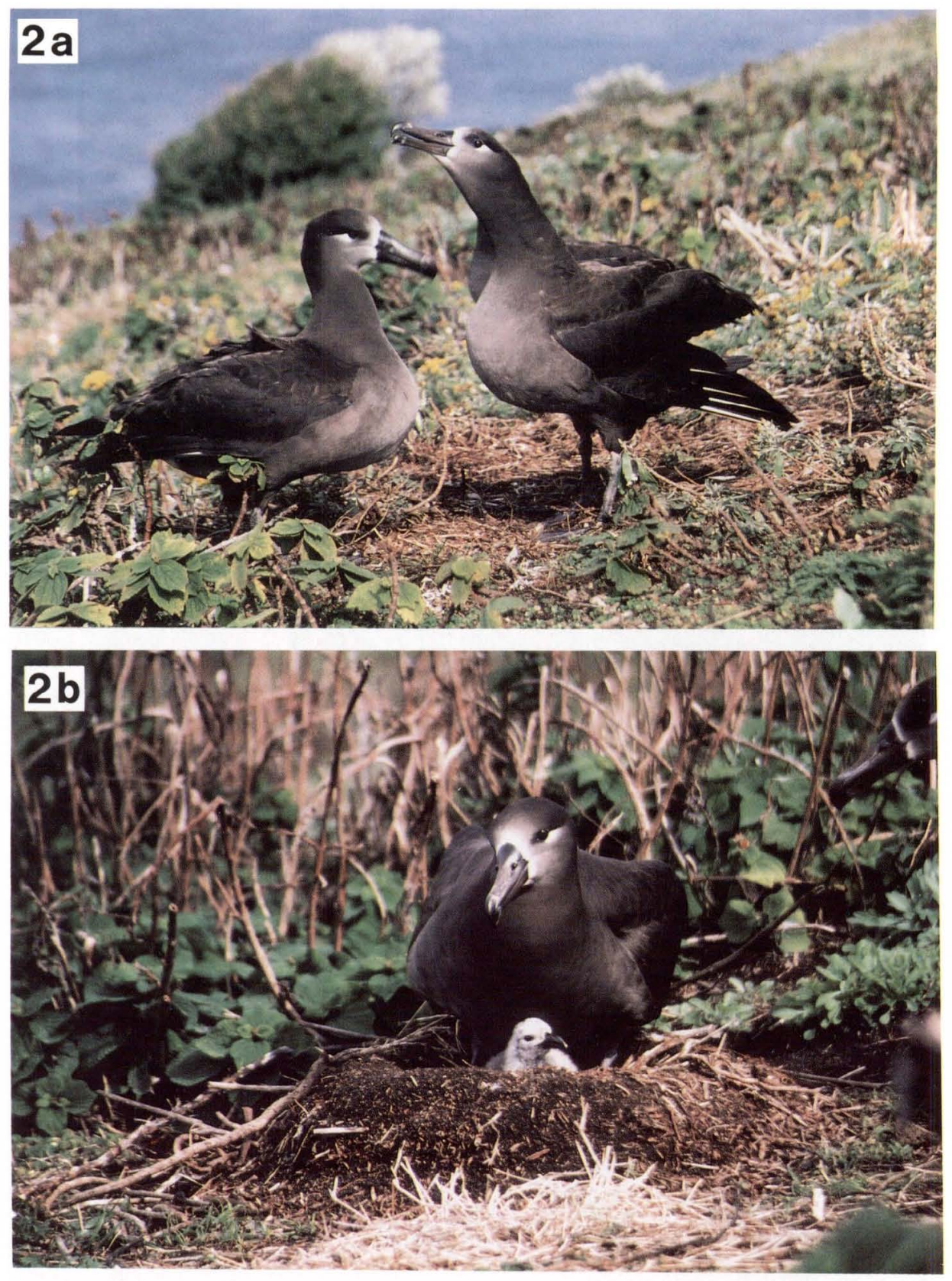

Plate 2a. Black-footed Albatrosses in courtship display at Hatsunezaki on Torishima Island. (January 26, 1994)

Plate 2b. A breeding Black-footed Albatross with its hatchling at Hatsunezaki on Torishima Island. (January 26, 1994) 